what he supposes to be the $a$ direction. The pebbles which he describes are, however, lengthened on the average $25^{\circ}$ east of north, with a plunge of $24^{\circ}$ in that direction.

The lineation of the metamorphic rocks in certain parts of Shetland was studied during the Geological Survey's rcutine examination of these islands (T. Robertson, 1938, "Observations on the Direction of Lineation in parts of Shetland," Summ. Progr. Geol. Surv. for 1936, part 2, p. 75). This applies, in particular, to an irregular belt, running across the group, from Vementry, west of the "Mainland", to the Outer Skerries, well to the east of the same main constituent, a total distance of about 25 miles. Throughout the belt the direction valies only from nearly due north and south to north-east. Dr. Flinn's lineations, if continued in thei own line, would fit in well with Robertson's observations, and one may infer that there is a certain regularity, probably applying to all the lineated part of Shetland.

Reverting to the simile, used in the writer's 1948 paper, of the movement of a pack of cards, lying on a flat table, it may be suggested that the uppermost cards have moved either north or south, in relation to those below. This can only represent very roughly what has happened in Shetland, in view (1) of the lineation dips, and (2) of the large displacements discussed by Read (1934, Quart. Journ. Geol. Soc., xc, 637) and others. It implies an $a$ lineation, but appears to the writer to give a better explanation of the extension of the pebbles described than that of Dr. Flinn's paper.

62 Greenbank Crescent,

E. M. Anderson. EDINBURGH.

October, 1952.

\title{
MUGEARITES AND OLIGOCLASE-BASALTS
}

SIR,-My old friend Professor Walker, in his recent article " Mugearites and Oligoclase-Basalts" (Geol. Mag., lxxxix, p. 337), refers to my description of mugearites in "The Geology of North Ayrshire" (Mem. Geol. Surv., 1930, pp. 105-8) but, owing to a temporary oversight (for which he has hastened to express regret by air-mail), fails to direct his readers' attention to p. 89 of that publication, where a reference will be found to a paper entitled "The Classification of Scottish Carboniferous Olivine-basalts and Mugearites" (Trans. Geol. Soc. Glasgow, xviii, pt. ii, 1928, p. 324). In this paper I devoted four pages to the history of the classification of Scottish mugearites, and drew attention to H. S. Washington's "olivine-oligoclaseandesites " of Hawaii, to H. H. Thomas's pre-Upper Llandovery mugearites of Pembrokeshire, and to A. K. Wells's views (of 1924) on the classification of mugearites. I dealt with the use of the name mugearite in Geological Survey publications in more detail than Professor Walker, and worked out a comprehensive definition of the term which seems to differ little from the one he now proposes. At a later date I adopted the current view that mugearite is a special variety of trachybasalt (op. cit., 1928, p. $349 ; 1939$, p. 89).

Professor Walker's article is timely, and will prove of interest to those who deal with volcanic petrology. I agree that the abandonment of the term "oligoclase-andesite" should be considered by Hawaiian petrologists. I believe, however, that no definition of mugearite will make it less difficult to solve two problems: (1) the naming of rocks transitional from mugearite to fine-grained basalt with fluxional parallelism of feldspars ; (2) the recognition of the original composition of the tiny sub-parallel albitic feldspars of lavas that resemble mugearites but are not "fresh-looking" (op. cit., 1928, p. 348). In the case of (1) the term " basaltic mugearite " is often useful.

19 Grange Terrace,

A. G. MACGregor.

EDINBURGH.

13th October, 1952. 